\title{
Over-Investment of Free Cash Flow during CEO's Tenure
}

\author{
Xia Jiang \\ College of Management, Jinan University, Guangzhou, China \\ Email: r29875@126.com
}

Received 24 May 2016; accepted 25 July 2016; published 28 July 2016

Copyright (C) 2016 by author and Scientific Research Publishing Inc.

This work is licensed under the Creative Commons Attribution International License (CC BY). http://creativecommons.org/licenses/by/4.0/

c) (7) Open Access

\begin{abstract}
This paper examines the relationship between CEO's tenure and their firm's investment efficiency. Over-investment is greater in the early years than in the later years of CEO's service. Consistent with prior literature, the results also suggest over-investment increases with firm's internallygenerated cash flow.
\end{abstract}

\section{Keywords}

\section{Over-Investment, Free Cash Flow, Tenure}

\section{Introduction}

This paper examines firm investment decisions during CEO's tenure. In theory, managers should invest projects with positive NPV to maximize the value of shareholders. However, prior research has found that managers don't always pick value maximizing projects. Richardson takes a sample of 1496 firms for the period of 19972002 and finds that over-investment is concentrated in firms with the highest level of free cash flow [1]. Yu et al. take a sample of A-share companies between 2004-2010 and find that over-investment exists both in stateowned and non state-owned companies [2]. Jensen and Meckling find top management has motivations to cause their firms to grow beyond the optimal size, even at the price of shareholders' interests [3]. Conyon and Murphy find that managers' compensation increases with firm's size, and managers in big firms have more income than their counterparts in small companies [4]. Due to opportunist motives, managers are likely to invest firms' cash flow into unprofitable projects to increase private interests.

Prior research mostly implicitly indicates that managers are homogenous, which is inconsistent with reality. According to upper echelons theory, a firm's behavior can be affected by management's background characteristics, including gender, age, education, tenure and so on. Investment decision is among many important decisions managers must make, and can also be affected by managers' characteristics. Pan et al. take the sample of 
5420 CEOs that take office between 1980 and 2009, and find the asset growth tends to be 3.2 percentage points lower in the later years of a CEO's tenure than in his first three years in office [5]. This paper focuses on examining how CEO's tenure influence a firm's investment efficiency with the sample of A-share companies for the period of 2008-2014.

One of the key questions is how to measure a firm's over-investment. This paper uses the model of Richardson to measure over-investment. Richardson's model is widely used in investment efficiency literature in China (e.g. Zhang [6]; Bai \& Lian [7]). Zhan et al. compare the advantages and disadvantages of Fazzari's FHP model, Vogt's model, and Richardson's model, and conclude that Richardson's model can not only be used to measure over-investment, but also help to research factors affecting investment efficiency [8]. This paper also uses Richardson's model to measure over-investment. I find there is a positive relationship between over-investment and cash flow, and the positive relationship is greater in the early years of CEO's tenure.

The contribution of this paper is to examine manager's investment decisions during the tenure. Prior studies on investment efficiency mainly focus on over-investment under implicit hypothesis that managers are homogeneous. In this paper, I introduce managers' tenure into over-investment analysis and provide direct evidence on the relation between over-investment and tenure.

The rest of the paper is organized as follows. Section 2 reviews the related literature and presents the hypotheses. Section 3 is the methodology used in this paper. Section 4 describes the sample selection process. Section 5 discusses empirical results, and Section 6 is the conclusions and implications.

\section{Literature Review and Research Hypotheses}

\subsection{Free Cash Flow and Over-Investment}

Prior research has confirmed that over-investment exists in firms. Harford uses a sample of 487 takeover bids, and finds that firms with large amount of cash are more likely to make acquisitions which subsequently experience abnormal declines in operating performance [9]. Bates takes a sample of 400 subsidiary sales from 19901998 and finds that firms retaining cash tend to invest more relative to industry peers [10]. Richardson develops a reliable model to measure a firm's over-investment and finds a positive relation between over-investment and cash flow [1]. Zhang et al. take a sample of 301 manufacturing firms listed on Shanghai and Shenzhen Stock Exchange between 2001 and 2006, and find that $39.26 \%$ of them are over-invested [6].

Over-investment may become severe in the presence of rich internally generated cash flow. In perfect capital markets, a firm's investment activities would not be influenced by internally generated cash flow. If a firm needed additional cash to finance an investment activity it would simply raise that cash from external capital markets. If the firm had excess cash beyond that needed to fund available positive NPV projects (including options on future investment), it would distribute free cash flow to external markets. However, firms don't operate in such a perfect world. Capital market frictions may impede management's ability to raise cash flow from external capital markets. Firms with more volatile cash flows will want to retain cash for the periods when cash flow is low, and firms who find it more difficult to raise external capital will desire larger cash holdings (e.g., Opler et al. [11]). In addition, management don't always act to maximize shareholders' value. When managers' objectives differ from those of shareholders, managers may squander internally generated cash flow. Prior studies suggest managers have motives to invest more, even at the expense of shareholders' interests. Conyon and Murphy find that managers' compensation increases with firm size, and managers in big firms have more income than their counterparts in small companies [4]. Baker et al. find that the investment can provide more promotion opportunities for middle management, which may bias managers towards investment [12]. Wang et al. find that the manager can decrease a firm's investment efficiency by reducing dividend payment [13]. So management may engage in additional investment on self-serving projects rather than distribute the cash to shareholders. Thus the first hypothesis is:

H1: Firms with rich free cash flow over-invest.

\subsection{CEO's Tenure and Over-Investment}

Prior studies mostly base their conclusions on the implicit hypothesis that managers have the same characteristics, which is inconsistent with the reality. According to upper echelons theory, which is proposed by Hambrick and Mason, management's background characteristics, including tenure, can influence their perceptibility, value 
and behavior, which will in turn influence the firms' decisions [14]. Empirical research suggests that management's background characteristics can influence a firm's innovation (Camelo [15]), business strategy (Tihanyi [16]), and accounting policy (Zhang [17]). Investment decision is one of many important decisions that management must make, and the relationship between over-investment and free cash flow may also be affected by CEO's tenure. Zhang et al. research the influence of management's tenure on research and development (R\&D) investment and find that there is a bell-shaped relationship between R\&D investment and management's tenure [18]. They explain that in the early years of tenure, managers have strong motives to achieve high performance and will increase R\&D investment. But managers will become slack and decrease R\&D investment beyond a turning point of their tenure. Lin and Lin take CEO's tenure as a proxy for specific human capital, and find that longer tenure brings higher investment efficiency [19].

As CEOs' tenure extends, CEOs can accumulate work experience, gain specific knowledge, and get profound understanding about many complex scenarios faced by the company, thus easily avoiding personal preference and making smart investment decisions. Main proposed that CEO should be offered longer contractual term than other employees, because longer term can help CEO invest in human capital and reduce the probability of inefficient investment decision because of lacking experience [20]. Moreover, the manager are more emotionally connected with the firm as his tenure extends, and considers more the firm's long-term goals and strategy when making investment decisions, which is helpful to decrease inefficient investment. From above analysis, I propose the second hypothesis:

H2: The over-investment of free cash flow is greater in the early years of CEOs' service than in the later years of CEOs' service.

\section{Methodology}

I use a cross-section model proposed by Richardson to estimate expected investment. He combines prior literature in economics and finance examining firm level investment decisions and suggests the following model to estimate expected investment.

$$
\begin{aligned}
I_{\mathrm{NEW}, t}= & \alpha+\beta_{1} \text { Growth }_{t-1}+\beta_{2} \text { Leverage }_{t-1}+\beta_{3} \text { Cash }_{t-1}+\beta_{4} \text { Age }_{t-1}+\beta_{5} \text { Size }_{t-1}+\beta_{6} \text { Stock Returns }_{t-1} \\
& +\beta_{7} I_{\mathrm{NEW}, t-1}+\sum \text { Year Indictor }+\sum \text { Industry Indictor }
\end{aligned}
$$

$I_{\mathrm{NEW}, t}$ is a firm's investment expenditure on new projects. The fitted value from the above regression is the estimate of the expected level of new investment, $I_{\mathrm{NEW}}^{*}$. The unexplained portion (or residual) is the estimate of over-investment, $I_{\mathrm{NEW}}^{\varepsilon}$. A firm's total investment can be divided into two main components: 1) required investment expenditure to maintain assets in place, $I_{\text {MAINTENANCE }}$, and 2) investment expenditure on new projects, $I_{\text {NEW }}$ (see Strong and Meyer [21]) for a similar decomposition). $I_{\text {TOTAL }}$ is the sum of all outlays on capital expenditure, acquisitions and research and development less receipts from the sale of property, plant and equipment:

$$
I_{\text {TOTAL }, t}=\text { CAPEX }_{t}+\text { Acquisitions }_{t}+\mathrm{RD}_{t}-\text { SalePPE }_{t}
$$

The proxy for $\mathrm{I}_{\text {MAINTENANCE }}$ is amortization and depreciation. Amortization and depreciation is an estimate of the portion of total investment expenditure that is necessary to maintain plants, equipment and other operating assets. $I_{\mathrm{NEW}}$ can be decomposed into expected investment expenditure in new positive NPV projects, $I_{\mathrm{NEW}}^{*}$, and abnormal (or unexpected) investment, $I_{\mathrm{NEW}}^{\varepsilon}$. The abnormal component of investment can be negative or positive. Positive (negative) values correspond to over- (under-)investment. This paper focuses on the overinvestment of free cash flow. Therefore, I will select positive residuals (estimates of over-investment) to do further research.

Expected investment is an increasing function of growth opportunity. I use the past two years' average sales growth as proxy of growth opportunity, instead of measures involving market price like book-to-market of equity (BM) and earnings-price ratios (EP). China's stock market is far from efficient, and the stock price is severely affected by investors' behavior and macroeconomic policies. The sales growth measure is widely used by Chinese researchers (e.g. Shen et al. [22]; Yu et al. [23]).

The additional control variables that have been shown in prior research to be determinants of investment decisions are included in the model, such as leverage, firm size, firm age, the level of cash, stock returns and prior firm level investment. Indicator variables for industry membership and temporal effects to capture additional 
variation in investment expenditure that are not explained by measures of growth opportunities and financing constraints are also included. The detailed definitions of these variables are in Table 1.

I firstly estimate the above equation using all observations for which required data are available on CSMAR database. The residuals of the regression are used as measures of inefficient investment. This paper focuses on over-investment, so I will choose positive residuals for further research. Then I use the following model to test hypothesis $\mathrm{H} 1$ and hypothesis $\mathrm{H} 2$.

$$
I_{\mathrm{NEW}}^{\varepsilon}=\alpha+\delta_{1} \mathrm{FCF}+\delta_{2} \text { Tenure }+\delta_{3} \mathrm{FCF} * \text { Tenure }+\varepsilon
$$

The dependent variable in this model is measures of over-investment. FCF is a firm's free cash flow. According to Richardson's definition, free cash flow is cash flow beyond what is necessary to maintain assets in place (including servicing existing debt) and to finance expected new investments. Free cash flow is calculated using the following two equations:

$$
\mathrm{FCF}=\mathrm{CF}_{\mathrm{AIP}}-I_{\mathrm{NEW}}^{*}
$$

$\mathrm{CF}_{\mathrm{AIP}}$ is a measure of cash flow generated from assets in place. $\mathrm{CF}_{\mathrm{AIP}}$ is computed by operating cash flow minus maintenance expenditure plus research and development (RD) expenditure. To compute free cash flow (FCF), expected new investment ( $I_{\mathrm{NEW}}^{*}$ ) is subtracted from cash flow generated from assets in place $\left(\mathrm{CF}_{\mathrm{AIP}}\right)$. I predict a positive coefficient on FCF (free cash flow), consistent with hypothesis H1 that over-investment is greater in the presence of larger free cash flow.

Tenure is an indicator variable that equals zero for firm-years that correspond to the first three years of CEOs' service, and is one otherwise. I consider the CEO change year and the two following years as early years. I predict a negative coefficient on Tenure, consistent with hypothesis $\mathrm{H} 2$ that over-investment is larger in the early years of CEO's service in the later years.

\section{Data and Sample Selection}

The empirical tests employ financial statement data and management characteristics data of A-share companies in CSMAR, covering the period of 2008-2014. I exclude financial institutions from my analysis because the demarcation between operating, investing, and financing activities is ambiguous for these firms. Besides, I exclude ST (Specially Treated) firms from my sample because financial data of these firms is abnormal. I also require that each industry-year group has at least ten observations. In the empirical analysis that follows I scale all financial variables by average total assets. The sample is also truncated at $1 \%$ to minimize the influence of outliers, and finally includes 6141 firm-year observations.

\begin{tabular}{|c|c|}
\hline Variables & Definition \\
\hline$I_{\mathrm{NEW}}$ & New Investment \\
\hline Growth & Growth rate of sales, proxy for investment opportunity \\
\hline Cash & Balance of cash and short term investments deflated by total assets measured at the start of the year \\
\hline Age & The log of the number of years the firm has been established \\
\hline Size & The log of total assets measured at the start of the year \\
\hline Stock Returns & $\begin{array}{l}\text { The stock returns for the year prior to the investment year. It is measured as the } \\
\text { change in market value of the firm over that prior year }\end{array}$ \\
\hline Year Indicators & A vector of indicator variables to capture annual fixed effects \\
\hline Industry Indicators & A vector of indicator variable to capture industry fixed effects. \\
\hline$I_{\mathrm{NEW}}^{\varepsilon}$ & An estimate of over-investment \\
\hline FCF & Free cash flow, cash flow beyond that necessary to maintain assets in place \\
\hline Tenure & CEO's tenure, indicator variables, 1 indicates CEO's tenure is more than 3 years, 0 less than 3 years \\
\hline
\end{tabular}

Table 1. Variables and definitions. 


\section{Empirical Results}

The empirical tests can be divided into two stages. Firstly, I use Richardson's model to measure over-investment. Over-investment is defined as investment expenditure beyond that required to maintain assets in place and to finance expected new investments in positive NPV projects (Richardson [1]). The fitted value from the regression is the estimate of the expected investment. The positive residual is the estimate of over-investment. Secondly, I regress the over-investment measure on free cash flow and CEO's tenure to research the relationship between over-investment and tenure and free cash flow.

The determinants of expected investment include growth opportunities, leverage, firm age, firm size, cash balance, industry fixed effects and annual fixed effects. Table 2 reports the regression results of the expected investment model after controlling year and industry fixed effect on expected investment. The signs of independent variables are consistent with expectation. The coefficient on cash is positive and significant, 0.047 (t-statistic $=4.89$ ), suggesting that firms with more retained cash significantly invest more. The coefficient of last period's investment is the biggest of all coefficients, with the coefficient equaling 0.339 (t-statistics = 27.16). Richardson finds the coefficient of prior investment is 0.386 (t-statistics $=45.65$ ), also the biggest of all coefficients [1]. The explanation power (Adjusted R-square) of the model is 0.205.

The fitted value of the model above is a firm's expected investment given certain investment opportunities, leverage and cash. The residual is an estimate of inefficient investment. The positive residual represents overinvestment, and the negative residual under-investment. This paper focuses on over-investment, so I choose observations with positive residuals for further research.

\begin{tabular}{|c|c|c|}
\hline Variables & Predicted Signs & Coefficients (t value) \\
\hline Intercept & & $\begin{array}{c}-0.075 \\
(-3.64)^{* * * *}\end{array}$ \\
\hline Cash & + & $\begin{array}{c}0.047 \\
(4.89)^{* * *}\end{array}$ \\
\hline Size & + & $\begin{array}{c}0.007 \\
(9.16)^{* * * *}\end{array}$ \\
\hline Growth & + & $\begin{array}{c}0.011 \\
(1.70)^{*}\end{array}$ \\
\hline Leverage & - & $\begin{array}{c}-0.019 \\
(-3.42)^{* * *}\end{array}$ \\
\hline$I_{\mathrm{NEW}, t-1}$ & + & $\begin{array}{c}0.339 \\
(27.16)^{* * * *}\end{array}$ \\
\hline Age & - & $\begin{array}{c}-0.014 \\
(-4.77)^{* * *}\end{array}$ \\
\hline StockReturns & + & $\begin{array}{l}0.002 \\
-0.86\end{array}$ \\
\hline YearIndicator & & Yes \\
\hline IndustryIndicator & & Yes \\
\hline Adjusted R2 & & 0.205 \\
\hline
\end{tabular}


Table 3 reports details on over-investment, free cash flow and tenure of observations having positive residuals. The mean over-investment of the subsample equals to 0.066 of its asset base, and the median 0.041 . The mean operating cash flow is 0.060 of assets. Tenure is an indicator variable that equals zero for firm-years that correspond to the first three years of CEOs' service, and is one otherwise in regression analysis. Table 3 reports managers' actual years of tenure. The mean (median) value of tenure is 2.73(2), and the maximum tenure is 13.The widespread distribution of tenure (with standard deviation equaling 2.83) guarantees the robustness of empirical results.

The second stage of empirical analysis is to research the relationship between over-investment and free cash flow and tenure. I regress over-investment on free cash flow and tenure, and the results are in Table 4. The model of over-investment in the first column of Table 4 includes only free cash flow as an explanatory variable. In the first model, the coefficient on free cash flow is $0.129(\mathrm{t}=6.38)$, suggesting that there is a significant positive relation between over-investment and cash flow. The result is consistent with prior literature. The second column of Table 4 includes only tenure as explanatory variable. The coefficient on tenure is $-0.013(t=-4.21)$, suggesting that there is a significant negative relation between over-investment and tenure. The third column includes both tenure and free cash flow and their interaction as explanatory variables, including the interaction between free cash flow and tenure. The coefficient of the interaction is $-0.207(t=-5.09)$, suggesting that the over-investment of cash flow decrease as CEO's tenure extends. After adding tenure and interaction into the model, Adjusted R-square rises to 0.0401, which indicates CEOs' tenure has explanatory power for over-investment.

The results above provide robust evidence for my hypotheses. In consistent with prior literature, I find a positive relation between cash flow and over-investment using Chinese A-share listed firms. Besides, I find CEO's tenure has explanatory power to over-investment even after controlling the effect of cash flow on over-investment. The result suggests that managers in early years of service tend to invest more inefficiently.

\section{Conclusions and Implications}

This paper, based on agency theory and upper echelons theory, examines the over-investment behavior during

Table 3. Descriptive statistics for dependent and independent variables.

\begin{tabular}{cccccc}
\hline Variables & Mean & Std Dev & Q1 & Median & Q3 \\
\hline$I_{\text {NEW }}^{\varepsilon}$ & 0.066 & 0.069 & 0.019 & 0.041 & 0.093 \\
FCF & 0.059 & 0.077 & 0.017 & 0.064 & 0.097 \\
Tenure & 2.73 & 2.83 & 0 & 2 & 5 \\
\hline
\end{tabular}

Table 4. Relation between over-investment and cash flow and tenure: $I_{\mathrm{NEW}}^{\varepsilon}=\alpha+\delta_{1} \mathrm{FCF}+\delta_{2}$ Tenure $+\delta_{3} \mathrm{FCF} * \mathrm{Tenure}+\varepsilon$.

\begin{tabular}{cccc}
\hline Variables & & Model & III \\
\cline { 2 - 4 } & I & II & 0.058 \\
Intercept & 0.059 & 0.074 & $(19.19)^{* * *}$ \\
FCF & $(30.14)^{* * *}$ & $(31.23)^{* * *}$ & 0.0252 \\
Tenure & 0.129 & & $(7.98)^{* * *}$ \\
FCF*Tenure & $(6.39)^{* * *}$ & -0.00058 \\
Adjusted R & & $(-4.21)^{* * *}$ & $(-0.15)$ \\
& & & -0.207 \\
\end{tabular}


CEOs' tenure. I predict that there is a positive relationship between over-investment and free cash flow, and the over-investment of free cash flow is severer in the early years of CEO's service than the later years. For the sample period 2008-2014, the empirical results show that, as expected, firms with rich free cash flow tend to over-invest, and the over-investment of free cash flow is larger in the early years than in the later years of CEOs' service.

The results not only help understand a firm's investment behavior, but also provide helpful guidelines to human resources management practices. This paper presents evidence that CEOs' tenure can influence a firm's investment efficiency. The over-investment of free cash flow is less in the later years of CEOs' service than in the early years of CEOs' service. As CEOs' tenure extends, they gain profound understanding of the business and thus can better evaluate a new investment project. From the perspective of investment efficiency, longer term CEO tends to make better investment decisions.

\section{References}

[1] Richardson, S. (2006) Over-Investment of Free Cash Flow. Review of Accounting Studies, 11, 159-189. http://dx.doi.org/10.1007/s11142-006-9012-1

[2] Yu, K., Li, Z.G., Zhang, X.R. and Xu, J.G. (2014) Investment Efficiency Puzzle: Financial Constraint Hypothesis and Monetary Policy Shock. Economic Research, 49, 106-120.

[3] Jensen, M.C. (1986) Agency Cost of Free Cash Flow, Corporate Finance, and Takeovers. Corporate Finance, and Takeovers. American Economic Review, 76, 323-329.

[4] Conyon, M.J. and Murphy, K.J. (2000) The Prince and the Pauper? CEO Pay in the United States and United Kingdom. The Economic Journal, 110, 640-671. http://dx.doi.org/10.1111/1468-0297.00577

[5] Pan, Y., Wang, T.Y. and Weisbach, M.S. (2013) CEO Investment Cycles (No. w19330). National Bureau of Economic Research. http://dx.doi.org/10.2139/ssrn.2307159

[6] Zhang, G.F. (2007) Is a Firm’s Free Cash Flow to Be Overinvested?_Evidence from China Listed Companies. Economics and Management Research, 11-16.

[7] Bai, J. and Lian, L.S. (2013) Why Do State-Owned Enterprises Over-Invest? Government Intervention or Managerial Entrenchment. China Journal of Accounting Studies, 1, 236-259.

[8] Zhan, L., He, J. and Hu, X.H. (2011) Overinvestment Research Model: Evaluation and Application. Finance and Accounting Monthly, No. 1, 94-97.

[9] Harford, J. (1999) Corporate Cash Reserves and Acquisitions. The Journal of Finance, 54, 1969-1997. http://dx.doi.org/10.1111/0022-1082.00179

[10] Bates, T.W. (2005) Asset Sales, Investment Opportunities, and the Use of Proceeds. The Journal of Finance, 60, 105-135. http://dx.doi.org/10.1111/j.1540-6261.2005.00726.x

[11] Opler, T., Pinkowitz, L., Stulz, R. and Williamson, R. (1999) The Determinants and Implications of Corporate Cash Holdings. Journal of Financial Economics, 52, 3-46. http://dx.doi.org/10.1016/S0304-405X(99)00003-3

[12] Baker, G., Gibbs, M. and Holmstrom, B. (1993) Hierarchies and Compensation: A Case Study. European Economic Review, 37, 366-378. http://dx.doi.org/10.1016/0014-2921(93)90025-6

[13] Wang, M.L., He, Y.R. and Lin, H.T. (2014) Managerial Power, Cash Dividends and Enterprises’ Investment Efficiency. Nankai Business Review, No. 2, 13-22.

[14] Hambrick, D.C. and Mason, P.A. (1984) Upper Echelons: The Organization as a Reflection of Its Top Managers. Academy of Management Review, 9, 193-206.

[15] Camelo-Ordaz, C., Hernández-Lara, A.B. and Valle-Cabrera, R. (2005) The Relationship between Top Management Teams and Innovative Capacity in Companies. Journal of Management Development, 24, 683-705. http://dx.doi.org/10.1108/02621710510613726

[16] Tihanyi, L., Ellstrand, A.E., Daily, C.M. and Dalton, D.R. (2000) Composition of the Top Management Team and Firm International Diversification. Journal of Management, 26, 1157-1177. http://dx.doi.org/10.1177/014920630002600605

[17] Zhang, Z.G., Liu, Y.W. and Qi, X.L. (2013) Research on Management Background Characteristics, Promotion Incentive and Over-Investment. Nankai Business Review, No. 4, 32-42.

[18] Zhang, Z.G., Liu, Y.W. and Yang, Q.X. (2014) Research on Management Tenure, Promotion Incentive and R\&D Investment. Accounting Research, No. 9, 81-88.

[19] Lin, C.N. and Lin, Y. (2014) Background Characteristics of Senior Managers and Investment Efficiency: Evidence from China's A-Share Listed Companies. Journal of Xiamen University, No. 2, 100-109. 
[20] Main, B. (1993) “Directors” Service Contracts, Why So Long. Hume Papers on Public Policy, No. 1, 36-41.

[21] Strong, J.S. and Meyer, J.R. (1990) Sustaining Investment, Discretionary Investment, and Valuation: A Residual Funds Study of the Paper Industry. In: Asymmetric Information, Corporate Finance, and Investment, University of Chicago Press, Chicago, 127-148.

[22] Shen, Y.F., Kuang, X.W. and Nie, Y.J. (2008) The Impact of Excess Control of Ultimate Controlling Shareholders on the Value of Cash Holdings. Nankai Business Review, No. 1, 31-38.

[23] Yu, H.H., Xu, L.B. and Chen, B.Z. (2010) The Control Right of Ultimate Controlling Shareholder and Overinvestment of Free Cash Flow. Economic Research, No. 8, 103-113.

\section{Submit or recommend next manuscript to SCIRP and we will provide best service for you:}

Accepting pre-submission inquiries through Email, Facebook, LinkedIn, Twitter, etc.

A wide selection of journals (inclusive of 9 subjects, more than 200 journals)

Providing 24-hour high-quality service

User-friendly online submission system

Fair and swift peer-review system

Efficient typesetting and proofreading procedure

Display of the result of downloads and visits, as well as the number of cited articles

Maximum dissemination of your research work

Submit your manuscript at: http://papersubmission.scirp.org/ 